\title{
How the Big Ten West Was Won: Football Recruiting
}

\begin{abstract}
The paper analyses the 2017 Big Ten West Division football cycle models recruiting. The top ten recruit scores $\left[\left(\right.\right.$ Rivals.com $\left.{ }^{*} 100\right)+[100$ (outside surrounding); 75 (surrounding) $]+$ extra credit walk-ons $\left.(100 ; 75)\right]$ allow proper ranking: Iowa, Nebraska, Wisconsin, Northwestern, Illinois, Minnesota, and Purdue.

Keywords: recruiting, Big Ten West Division, football, Rivals.com, 2017.

Straipsnyje analizuojamas Vakarų didžiojo dešimtuko diviziono žaidèjų pritraukimo modelis 2017 m., pristatomi universitetai, sèkmingai pritraukiantys futbolo atletus ((Rivals.com $\left.{ }^{\star} 100\right)+[100$ (ne kaimyninių valstijų); 75 (iš kaimyninių valstijų)] + papildomi taškai savanoriams atletams, kurie atvyko iš ne kaimyninių valstijų (100; 75)]): Iowa, Nebraska, Wisconsin, Northwestern, Illinois, Minnesota ir Purdue.
\end{abstract}

Raktiniai žodžiai: pritraukimas, Vakarų diviziono didysis dešimtukas, futbolas, Rivals.com, 2017.

\section{Introduction}

Recruiting is the life blood of any organization (Treadway et al., 2014). So important is it to the ultimate success of a company that leaders' skills in this area should be a primary emphasis of research (Treadway et al., 2014). Unfortunately, this emphasis is less than what it should be, even in so covered an area of as coaching and recruiting, an ideal model environment for studying general management principles.

As such, this paper seeks not only to bring a renewed consideration to recruiting skill but to do so in a novel way. It considers for one of the first times how well a coach recruits by looking at the distance between a university and a player as a key determinant in assessing individual coaching recruiting skill. Lessons learned are then advanced and generalized for managers in other areas.

The research object of this paper is to examine who is best at recruiting football personnel by comparing and contrasting recruiting scores after adjustment to consider important elements, distance to recruit and preferred walk-ons. It specifically considers college football recruiting as a model from which to gain lessons for all recruiting in general.

The tasks include utilizing the Rivals. com scoring database for football recruits with the following adjustments:

- The product of each score (from 5.1 through 6.1) and 100 is an intermediate step.

- To this product are added 100 points for a recruit from outside the surrounding states, 75 points for a recruit from the surrounding states, and -0- points or a recruit from the state of the university.

- Finally, only the top 10 scores are considered to adjust for differences in recruiting class sizes.

- Extracreditisgiven for out-of-state preferred walk-ons (same 100 v. 75 point adjustments). 
The research methods include the use of multiplication and addition. More precisely, direct comparisons are utilized among universities' recruiting scores.

The research results include the following findings. The order of recruiting finish in the Big Ten West Division for 2017 is: Iowa, Nebraska, Wisconsin, Northwestern, Illinois, Minnesota, and Purdue. Many lessons are learned. First, historical success on the field does little to affect current recruiting. Current results do influence current recruiting. Second, while the Rivals.com database has the perception of creating large disparities between teams in deriving scores, it in the end creates minimal differences with its actual scoring numbers used instead of star rankings in assessing teams' recruiting success.

\section{How the Big Ten West Was Won: football recruiting}

\section{Literature review}

With the approval of its constituent members, the National Collegiate Athletic Association (NCAA) oversees recruiting of high school football players (Bricker, Hanson, 2003). National signing day occurs annually in early February. Universities football teams complete their recruiting process by officially signing national letters of intent, formalizing their previous verbal commitments (Bricker, Hanson, 2003). Each team may sign up to 25 football players to athletic scholarships. The NCAA permits these teams to have 85 scholarship and 105 football players in total. The difference between 85 and 105 comes from preferred walk-ons (Bricker, Hanson, 2003). In the end then, college football players are the equivalent of employees even though they do not technically receive wages (Rosenberger, 2014). Thus, this area of study becomes a model for general management recruiting principles.

Recruiting is so important because it directly affects how well a team plays on the field (Caro, 2012; Langelett, 2003). Some question how strong the correlation is between recruiting and wins (Bergman, Logan, 2014), suggesting that successful recruiting is 25 percent less impactful than previous studies suggest because of heterogeneity between teams. Nevertheless, in the end then, even the cynics still find statistically significant correlations between successful recruiting and wins (Bergman, Logan, 2014).

In fact, the monetary impact of a higher quality recruit on revenue for athletic departments can be $\$ 150,000$ more for a fivestar recruit (Bergman, Logan, 2014). Another study suggests that a quality football player can generate upwards of $\$ 500,000$ each year for his team (Brown, 1993).

Recruiting also strongly influences chief executive officers of football teams (coaches), regarding not only their ability to maintain employment but also to rise through the ranks to more lucrative postings (Treadway et al., 2014; Maxcy, 2013).

To be fair here, while recruiting is important, it is not everything. As with all managers in general, a coach's ability to develop players' skills, once they are secured, is equally important (Maxcy, 2013).

At the end of the day, though, individual recruiting qualities of a particular coach most strongly determine team recruiting success, especially because teams with poor records can still get stellar recruits (Treadway et al., 2014). More specifically, effective recruiters are more capable of identifying relevant choice 
factors, packaging this information in influential communications with prospective recruits, and utilizing persuasive tactics to get great players with a great fit (Magnusen et al., 2014).

This recruiting success then changes future records for the better (Treadway et al., 2014). Indeed, the fact that coaches' individualized political skills in recruiting players can outweigh team success on the field illustrates how important it is to evaluate football coaches' recruiting skills in hiring decisions (Treadway et al., 2014). Successful recruiting is more than just getting the best player. Challenging, though, for coaches is that the best athletes tend to delay their commitment decisions. In fact, athletes with earlier verbal commitments tend to play less than athletes with later verbal commitments (Bricker, Hanson, 2003). The fit of the player with the team is important as well, part of each coach's recruiting skill (Brown, Farrell, Zorn, 2007).

Once this coaching recruiting skill is evidenced and brings results, however, excellent recruiting can create a reinforcing cycle (Caro, 2012; Langelett, 2003). Precisely, as a team wins more, it gets better recruits. As it gets better recruits, it wins more (Caro, 2012; Langelett, 2003). As such, some teams are consistently top 25 teams likely while others rarely, if ever, are (Caro, 2012; Langelett, 2003). Indeed, for the Big Ten teams, 63 to 80 percent of success on the field relates to recruiting success (Caro, 2012).

The players' decisions on what university to attend rely on geographic distance between the athlete and the university (Dumond, Lynch, Platania, 2008). However, the current Rivals.com recruiting database does not give any extra points for recruiting players from surrounding states or even more adroitly recruiting players from outside the surrounding states. Likewise, current recruiting scoring does not consider how deft a coach must be to get players to walk on for no compensation (no scholarship) from outside the state.

Players who grow up in a state supporting a given team are more likely to play for that team (Dumond et al., 2008). Thus, coaches who can get good players from outside the area are particularly adroit.

Other factors do affect recruiting (Dumond et al., 2008). Yes, the team's current ranking does affect recruiting. Interestingly, whether the team is in a power conference additionally influences recruiting (Caro, 2012; Dumond et al., 2008).

A power conference is one of the top five football conferences in the US (Maxcy, 2008). Teams from them are eligible for the Bowl Championship Series (BCS) (Caro, 2012; Dumond et al., 2008). Such teams have more access to prestigious bowls, such as the national championship game (Caro, 2012), and generally have more revenue in their athletic departments (Caro, Benton, 2012).

To get stellar recruits, these universities offer the top development available to recruits (Caro, Benton, 2012). It begins with top-of-the-line weight-lifting equipment to help players get stronger and faster (Czekanski, Barnhill, 2015). Also, they secure the best coaches, with the capability to pay the highest salaries (Caro, Benton, 2012). Great coaching leads to greater skill development, an additional benefit to prospective top recruits (Maxcy, 2013).

\section{Sample}

The sample is the Big Ten West Division for football year 2017. While larger data sets can provide more robustness 
in determining results, sometimes such information is not publicly available. As such, resort to smaller data sets is the only possibility on occasion (Liker, Fleischer, Arnsdore, 1992). So little as 6 companies with one year of data for each has been deemed to be sufficient for some studies due to the lack of available data (Liker et al., 1992).

\section{Methodology}

The research methodology begins by utilizing Rivals.com scores per athlete. The product of each score (from 5.1 through 6.1) and 100 is an intermediate step. Only the top 10 scores are considered to adjust for differences in recruiting class sizes.

The name identifies the player. Position stands for where the player is to play, such as OL for offensive lineman, TE for tight end, WR for wide receiver, $\mathrm{RB}$ for running back, QB for quarterback, DE for defensive end, DT for defensive tackle, LB for line-backer, and DB for defensive back. ATH indicates that the player can play a variety of positions.

Location is the place from which the player has been recruited. Height is in feet and inches. Weight is then given in pounds. Rivals means the Rivals.com score assigned. Times represents the product of the Rivals score and 100. Location signifies the points for a committed player outside the state: 100 (outside surrounding states) and 75 (surrounding state). Total is the score for each player (Times + Location $=$ ). The total overall team score is then bolded.

Extra credit points are given for preferred walk-ons. Indeed, they do not get a scholarship initially (if ever): 100 (outside surrounding states), 75 (surrounding states), and -0- (in state).

\section{Results}

University of lowa results

\begin{tabular}{|c|c|c|c|c|c|c|c|c|}
\hline Name & Position & Location & Height & Weight & Rivals & Times & Location & Total \\
\hline Kyshaun Bryan & $\mathrm{RB}$ & Ft. Lauderdale, FL & 5'10" & 185 & 5.7 & 570 & 100 & 670 \\
\hline Matt Hankins & DB & Flower Mound, TX & 6'1" & 160 & 5.7 & 570 & 100 & 670 \\
\hline Peyton Mansell & QB & Belton, TX & $62 "$ & 205 & 5.7 & 570 & 100 & 670 \\
\hline Djimon Colbert & DB & Shawnee Mission, KS & 6’1" & 186 & 5.7 & 570 & 100 & 670 \\
\hline Trey Creamer & DB & Cartersville, GA & 6’" & 175 & 5.6 & 560 & 100 & 660 \\
\hline A. J. Epenesa & $\mathrm{DE}$ & Edwardsville, IL & $65^{\prime \prime}$ & 270 & 6.1 & 610 & 75 & 685 \\
\hline Ihmir Smith-Marsette & ATH & Newark, NJ & $62^{\prime \prime}$ & 175 & 5.5 & 550 & 100 & 650 \\
\hline Josh Turner & DB & Delray Beach, FL & 6’" & 180 & 5.5 & 550 & 100 & 650 \\
\hline Brandon Smith & WR & Lake Cormorant, MS & $63^{\prime \prime}$ & 198 & 5.5 & 550 & 100 & 650 \\
\hline \multirow[t]{3}{*}{ Geno Stone } & DB & New Castle, PA & $60^{\prime \prime}$ & 188 & 5.4 & 540 & 100 & 640 \\
\hline & & & & & & & & 6615 \\
\hline & & & & IL QB & $\begin{array}{l}\text { WISC } \\
\text { TE }\end{array}$ & $\begin{array}{l}\text { WISC } \\
\text { LB }\end{array}$ & KS WR & \\
\hline Extra credit & & & & 75 & 75 & 75 & 100 & 6940 \\
\hline
\end{tabular}


What allows Iowa's scores to be so high is the combination of recruiting ten players from outside the state of high quality and many out-of-state preferred walk-ons. Particularly unique is the ability to have a player from a surrounding state fit in the top ten scores. A. J. Epenesa has such a high opening Rivals.com score that the fact he is only from a surrounding state (75 points) still does not prevent him from becoming a top-ten score for Iowa.

As the paper has mentioned, a coach is particularly good at recruiting political skill by getting players from outside the surrounding states. A coach has even greater political skill if he can convince a recruit (an employee) to play for the school without any compensation (no scholarship). The ability to get four preferred walk-ons is an incredible accomplishment.

Nebraska does well at getting players from outside the surrounding states. Similarly, the school is particularly successful because of getting an out-of-state preferred walk-on. If the Nebraska coach did an even better job communicating the benefits of attending Nebraska so as to get more players from outside the state to walk on, the score would have bettered Iowa's. After all, Nebraska's recruits have higher individual Rivals.com scores to begin.

The Nebraska coach chooses to emphasize California more so than other schools. Such an emphasis enables him to accumulate higher overall scores given a tendency (because of population size) to secure more capable skill-position players from that area. Skill-position players generally are quarterbacks and wide receivers.

The Wisconsin coach deserves high marks for using his political skill to get players from multiple outside-the-surrounding-states areas. Many times, it is more difficult to get a player from a different state without also bringing in another player from the same state in that

University of Nebraska results

Table 2

\begin{tabular}{|l|c|l|c|c|c|c|c|c|}
\hline \multicolumn{1}{|c|}{ Name } & Position & \multicolumn{1}{c|}{ Location } & Height & Weight & Rivals & Times & Location & Total \\
\hline Tyjon Lindsey & WR & Las Vegas, NV & $5^{\prime} 9^{\prime \prime}$ & 175 & 6 & 600 & 100 & 700 \\
\hline Elijah Blades & DB & Pasadena, CA & $6^{\prime} 3^{\prime \prime}$ & 170 & 5.9 & 590 & 100 & 690 \\
\hline Avery Roberts & LB & Wilmington, DE & $6^{\prime} 1^{\prime \prime}$ & 213 & 5.9 & 590 & 100 & 690 \\
\hline Tristan Gebbia & QB & Calabasas, CA & $6^{\prime} 3^{\prime \prime}$ & 180 & 5.9 & 590 & 100 & 690 \\
\hline Guy Thomas & DE & Miami, FL & $6^{\prime} 3^{\prime \prime}$ & 205 & 5.8 & 580 & 100 & 680 \\
\hline Keyshawn Johnson Jr. & WR & Calabasas, CA & $66^{\prime} 1^{\prime \prime}$ & 195 & 5.8 & 580 & 100 & 680 \\
\hline Damion Daniels & DT & Dallas, TX & $6^{\prime} 2^{\prime \prime}$ & 310 & 5.7 & 570 & 100 & 670 \\
\hline Brenden J. & OL & Austin, TX & $66^{\prime \prime}$ & 260 & 5.7 & 570 & 100 & 670 \\
\hline Deiontae Watts & DT & Plano, TX & $63^{\prime \prime}$ & 290 & 5.6 & 560 & 100 & 660 \\
\hline Kurt Rafdal & TE & Carmel, IN & $6{ }^{\prime} 7^{\prime \prime}$ & 230 & 5.6 & 560 & 100 & 660 \\
\hline & & & & & & & & 6790 \\
\hline Extra credit & & & & & & AZ WR & 100 & $\mathbf{6 8 9 0}$ \\
\hline
\end{tabular}

Source: Rivals score from https://nebraska.rivals.com/commitments/football/2017. 
University of Wisconsin results

Table 3

\begin{tabular}{|l|c|l|c|c|c|c|c|c|}
\hline \multicolumn{1}{|c|}{ Name } & Position & \multicolumn{1}{c|}{ Location } & Height & Weight & Rivals & Times & Location & Total \\
\hline Danny Davis & WR & Springfield, OH & $6^{\prime} 2^{\prime \prime}$ & 180 & 5.9 & 590 & 100 & 690 \\
\hline Jonathan Taylor & RB & Salem, NJ & $5^{\prime} 10^{\prime \prime}$ & 201 & 5.8 & 580 & 100 & 680 \\
\hline Jack Coan & QB & Sayville, NY & $6^{\prime} 4^{\prime \prime}$ & 190 & 5.8 & 580 & 100 & 680 \\
\hline Izayah Green-May & DE & Bolingbrook, IL & $6^{\prime} 5^{\prime \prime}$ & 205 & 5.7 & 570 & 100 & 670 \\
\hline Cade Green & WR & Austin, TX & $6^{\prime} 0^{\prime \prime}$ & 187 & 5.7 & 570 & 100 & 670 \\
\hline Scott Nelson & ATH & Detroit, MI & $6^{\prime} 2^{\prime \prime}$ & 180 & 5.6 & 560 & 100 & 660 \\
\hline Emmet Perry & WR & DeSoto, TX & $6^{\prime} 2^{\prime \prime}$ & 165 & 5.6 & 560 & 100 & 660 \\
\hline Faion Hicks & ATH & Pembroke Pines, FL & $5^{\prime} 10^{\prime \prime}$ & 180 & 5.6 & 560 & 100 & 660 \\
\hline Madison Cone & DB & Kernersville, NC & $5^{\prime} 10^{\prime \prime}$ & 165 & 5.6 & 560 & 100 & 660 \\
\hline Andrew V. G. & DE & Council Bluffs, IA & $66^{\prime \prime}$ & 240 & 5.8 & 580 & 75 & 655 \\
\hline & & & & & & & & $\mathbf{6 6 8 5}$ \\
\hline
\end{tabular}

Source: Rivals score from https://wisconsin.rivals.com/commitments/football/2017

recruiting class. This particular issue has been overcome with great political skill in recruiting. The evidence appears in a player from Ohio, New Jersey, New York, Illinois, Texas, Michigan, Florida, North Carolina, and lowa appearing in their top ten. Only Texas has repetition in that listing.
However, this coach could improve on securing preferred walk-ons from out of state. Such an activity improves the depth of the roster at no additional cost.

Because of a smaller fan base and a more demanding academic environment, Northwestern could face some recruiting

\section{Northwestern University}

Table 4

\begin{tabular}{|l|c|l|c|c|c|c|c|c|}
\hline \multicolumn{1}{|c|}{ Name } & Position & \multicolumn{1}{c|}{ Location } & Height & Weight & Rivals & Times & Location & Total \\
\hline Trey Pugh & TE & Plain City, OH & $6^{\prime} 5^{\prime \prime}$ & 225 & 5.7 & 570 & 100 & 670 \\
\hline Trevor Kent & DE & Pittsburg, KS & $6^{\prime} 4^{\prime \prime}$ & 252 & 5.7 & 570 & 100 & 670 \\
\hline Earnest Brown & DE & Denton, TX & $6^{\prime} 5^{\prime \prime}$ & 230 & 5.7 & 570 & 100 & 670 \\
\hline Ethan Wiederkehr & OL & Shoreham, NY & $6^{\prime} 6^{\prime \prime}$ & 285 & 5.6 & 560 & 100 & 660 \\
\hline J.R. Pace & DB & College Park, GA & $6^{\prime} 1^{\prime \prime}$ & 170 & 5.6 & 560 & 100 & 660 \\
\hline Peter McIntyre & LB & Toledo, OH & $6^{\prime} 2^{\prime \prime}$ & 210 & 5.6 & 560 & 100 & 660 \\
\hline Austin Hiller & DB & Austin, TX & $6^{\prime} 2^{\prime \prime}$ & 201 & 5.6 & 560 & 100 & 660 \\
\hline Rashawn Slater & OL & Sugar Land, TX & $6^{\prime} 5^{\prime \prime}$ & 275 & 5.6 & 560 & 100 & 660 \\
\hline Sam Miller & DE & Houston, TX & $6^{\prime} 3^{\prime \prime}$ & 260 & 5.6 & 560 & 100 & 660 \\
\hline Sam Gerak & OL & Avon, OH & $64^{\prime \prime}$ & 285 & 5.6 & 560 & 100 & 660 \\
\hline & & & & & & & & $\mathbf{6 6 3 0}$ \\
\hline
\end{tabular}

Source: Rivals score from https://northwestern.rivals.com/commitments/football/2017. 
University of Illinois results

Table 5

\begin{tabular}{|l|c|l|c|c|c|c|c|c|}
\hline \multicolumn{1}{|c|}{ Name } & Position & \multicolumn{1}{c|}{ Location } & Height & Weight & Rivals & Times & Location & Total \\
\hline Owen Carney & DE & Miami, FL & $6^{\prime} 3^{\prime \prime}$ & 231 & 5.8 & 580 & 100 & 680 \\
\hline Carmoni Green & WR & Miami, FL & $6^{\prime} 1^{\prime \prime}$ & 178 & 5.8 & 580 & 100 & 680 \\
\hline Delshawn Phillips & LB & Garden City, KS & $6^{\prime} 2^{\prime \prime}$ & 230 & 5.6 & 560 & 100 & 660 \\
\hline Mike Epstein & RB & Fort Lauderdale, FL & $6^{\prime} 0^{\prime \prime}$ & 182 & 5.6 & 560 & 100 & 660 \\
\hline Dwayne Lawson & QB & Garden City, KS & $6^{\prime} 6^{\prime \prime}$ & 225 & 5.6 & 560 & 100 & 660 \\
\hline Howard Watkins & OL & Cincinnati, OH & $6^{\prime} 5^{\prime \prime}$ & 280 & 5.6 & 560 & 100 & 660 \\
\hline Deon Pate & DE & Jacksonville, FL & $6^{\prime} 3^{\prime \prime}$ & 233 & 5.5 & 550 & 100 & 650 \\
\hline Ra'Von Bonner & RB & Cincinnati, OH & $5^{\prime} 11^{\prime \prime}$ & 205 & 5.5 & 550 & 100 & 650 \\
\hline Jamal Woods & DE & Hueytown, AL & $66^{\prime \prime}$ & 240 & 5.4 & 540 & 100 & 640 \\
\hline Larry Boyd & OL & St. Louis, MO & $6^{\prime} 5^{\prime \prime}$ & 320 & 5.7 & 570 & 75 & 645 \\
\hline & & & & & & & & $\mathbf{6 5 8 5}$ \\
\hline
\end{tabular}

Source: Rivals score from https://illinois.rivals.com/commitments/football/2017.

issues. However, the school's coach evidences great political skill in recruiting by looking to Texas. As California is for Nebraska, Texas seems to be for Northwestern. It is an area with a lot of skilled athletes, given the population size and the commitment to football there. Thus, Earnest Brown, Austin Hiller, Rashawn Slater, and Sam Miller could help recruit each other to the school. Similarly, Trey Pugh, Peter McIntyre, and Sam Gerak could have mutually reinforced their recruitments to the school from their Ohio ties. The lack of preferred walk-ons does not permit the final score to be competitive with teams above Northwestern in the order.

As Illinois's winning percentage has not been that good, the Illinois coach has done well to secure an excellent recruiting class. Florida is obviously a major area of emphasis. The result is that Owen Carney, Carmoni Green, Mike Epstein, and Deon Pate could mutually reinforce their commitments to the school. The Illinois coach may well have an assistant coach with ties to Florida to allow this significant percentage of players to commit from there. Unfortunately, the lack of quality preferred walk-ons from outside the state diminishes the chances of finishing higher in the rankings.

Because the Minnesota coach has less years at his job than others, this recruiting class is actually quite good. However, the lack of quality preferred walk-ons from out of state decreases the chances of climbing higher in the rankings.

Just as is the case for the Minnesota coach, the Purdue coach has less time in his post. In addition, Purdue does not have a recent history of high winning percentages. Nevertheless, this coach has been able to secure quality recruits from outside the area. The lack of preferred walk-ons, though, does stop Purdue from climbing higher in the rankings.

Iowa wins with 6940 total points. Nebraska follows with 6890 . Wisconsin then enters into the equation with 6685 . 
University of Minnesota results

Table 6

\begin{tabular}{|l|c|l|c|c|c|c|c|c|}
\hline \multicolumn{1}{|c|}{ Name } & Position & \multicolumn{1}{|c|}{ Location } & Height & Weight & Rivals & Times & Location & Total \\
\hline Adam Beck & DB & Richmond, TX & $6^{\prime} 2^{\prime \prime}$ & 184 & 5.7 & 570 & 100 & 670 \\
\hline Mohamed Ibrahim & RB & Olney, MD & $5^{\prime} 9^{\prime \prime}$ & 185 & 5.7 & 570 & 100 & 670 \\
\hline Demetrius Douglas & ATH & Portland, OR & $5^{\prime} 11^{\prime \prime}$ & 175 & 5.6 & 560 & 100 & 660 \\
\hline Jake Paulson & TE & Louisville, KY & $6^{\prime} 5^{\prime \prime}$ & 245 & 5.6 & 560 & 100 & 660 \\
\hline Christopher Bell & WR & Kankakee, IL & $6^{\prime} 1^{\prime \prime}$ & 185 & 5.6 & 560 & 100 & 660 \\
\hline Malcolm Robinson & DT & Massillon, OH & $66^{\prime \prime}$ & 280 & 5.5 & 550 & 100 & 650 \\
\hline Justus Harris & DB & Roswell, GA & $5^{\prime} 10^{\prime \prime}$ & 170 & 5.5 & 550 & 100 & 650 \\
\hline K. Handy-Holly & DB & Jackson, AL & $62^{\prime \prime}$ & 194 & 5.5 & 550 & 100 & 650 \\
\hline Nate Umlor & TE & Allendale, MI & $66^{\prime \prime}$ & 245 & 5.5 & 550 & 100 & 650 \\
\hline J. M. Schmitz & OL & Homewood, IL & $66^{\prime \prime}$ & 280 & 5.5 & 550 & 100 & 650 \\
\hline & & & & & & & & $\mathbf{6 5 7 0}$ \\
\hline
\end{tabular}

Source: Rivals score from https://minnesota.rivals.com/commitments/football/2017

Purdue University

Table 7

\begin{tabular}{|l|c|l|c|c|c|c|c|c|}
\hline \multicolumn{1}{|c|}{ Name } & Position & \multicolumn{1}{|c|}{ Location } & Height & Weight & Rivals & Times & Location & Total \\
\hline T. J. Jallow & DB & Scooba, MS & $6{ }^{\prime} 2^{\prime \prime}$ & 210 & 5.6 & 560 & 100 & 660 \\
\hline Dedrick Mackey & DB & Miami, FL & $5^{\prime} 11^{\prime \prime}$ & 165 & 5.6 & 560 & 100 & 660 \\
\hline Nicholas Sipe & QB & Villa Park, CA & $6^{\prime} 4^{\prime \prime}$ & 190 & 5.6 & 560 & 100 & 660 \\
\hline Terry Wright & WR & Coffeyville, KS & $6^{\prime} 0^{\prime \prime}$ & 170 & 5.5 & 550 & 100 & 650 \\
\hline Viktor Beach & OL & Fort Myers, FL & $6^{\prime} 5^{\prime \prime}$ & 285 & 5.5 & 550 & 100 & 650 \\
\hline $\begin{array}{l}\text { D'Jaundrae } \\
\text { Edwards }\end{array}$ & WR & West Palm Beach, FL & $66^{\prime} 2^{\prime \prime}$ & 180 & 5.5 & 550 & 100 & 650 \\
\hline Darius Pittman & WR & Bay Saint Louis, MS & $6^{\prime} 3^{\prime \prime}$ & 225 & 5.5 & 550 & 100 & 650 \\
\hline Jalen Jackson & OL & Powder Springs, GA & $6^{\prime} 3^{\prime \prime}$ & 255 & 5.5 & 550 & 100 & 650 \\
\hline Ethan Smart & OL & Boonesville, MS & $6^{\prime} 6^{\prime \prime}$ & 290 & 5.5 & 550 & 100 & 650 \\
\hline Tyler Hamilton & WR & Hilton Head, SC & $5^{\prime} 9^{\prime \prime}$ & 160 & 5.5 & 550 & 100 & 650 \\
\hline & & & & & & & & $\mathbf{6 5 3 0}$ \\
\hline
\end{tabular}

Source: Rivals score from https://purdue.rivals.com/commitments/football/2017. 
Northwestern comes next with 6630. Illinois follows with 6585. Minnesota then has 6570. Finally, Purdue scores 6530.

Virtually every team recruits at least ten players from outside the surrounding states. Wisconsin is the exception.

What makes the biggest difference is the fact that Iowa and Nebraska have secured preferred walk-ons from outside their state. They are truly extra credit as they agree to participate without any guarantee of ever receiving a scholarship. Getting them from in state is little to no challenge as players without any offers obviously can end up attending the in-state school anyway.

Nonetheless, getting somebody to play for the team and pay out-of-state tuition is a huge coup. In fact, coaches' time is so valuable that they would not likely spend it hoping for a miracle in getting such a player unless they are worth the effort. After all, there is the risk that a competitor could offer a scholarship at the end of the process to pry that player away from the preferred walk-on status.

Finding a way to get such players can make a huge difference in teams as many walk-ons do become valuable contributors. In fact, many Iowa players over the years have walked on and been so good that they have gone on to professional careers.

\section{Implications}

To test the robustness of these results, the recruiting classes of Alabama and Clemson, the two national title contenders, are separately analysed and compared to these results. Both would have led the Big Ten West Division in recruiting, which helps demonstrate the adequacy of the methodology.
Moving forward, coaches should emphasize acquiring preferred walk-ons from outside the state. Securing such skilled athletes without providing any scholarship is a sort of free way of improving the quality of the team through depth.

Further research can address other areas that show the skill of coaches and recruiting. This study could be replicated for other sports not only to discern who is an effective recruiter in those areas but also to determine how supportable this methodology is for other sports.

This study is generalizable to general management. More specifically, securing unpaid interns from universities can be a sort of free way to improve the quality of a company's employees. The preferred walk-ons do operate as interns in a sense. If they prove valuable, they gain scholarships. It is in the same way that interns who prove valuable become full-time employees.

Again, this finishing order indicates that the University of Iowa football coach exhibits the best political skill at convincing recruits to attend the university. $\mathrm{He}$ evidently knows how to emphasize his university's strengths and minimize its weaknesses at a level higher than others in the Big Ten West Division.

This discovery allows future researchers to emphasize what he does in particular to recruit better players. This result also is educational to managers outside the football arena.

Whereas other managers can choose to change compensation to levels higher than their competitors to get great employees, better still would be to learn from football coaches (in a capped compensation environment then) on how best to maximize strengths and minimize weaknesses in discussing their respective companies. 


\section{References}

1. Bergman, S. A., Logan, T. D. (2016). The Effect of Recruit Quality on College Football Team Performance // Journal of Sports Economics. Vol. 17, No. 6, p. 578-600.

2. Bricker, J., Hanson, A. (2013). The Impact of Early Commitment on [Contests] Played: Evidence from College Football Recruiting // Southern Economic Journal. Vol. 79, No. 4, p. 971-983.

3. Brown, R. W. (1993). An Estimate of the Rent Generated by a Premium College Football Player // Economic Inquiry. Vol. 31, No. 4, p. 671-684.

4. Brown, T., Farrell, K. A., Zorn, T. (2007). Performance Measurement \& Matching: The Market for Football Coaches // Quarterly Journal of Business and Economics. Vol. 46, p. 21-35.

5. Caro, C. A. (2012). College Football Success: The Relationship between Recruiting and Winning // International Journal of Sports Science \& Coaching. Vol. 7, No. 1, p. 139-152.

6. Caro, C. A., Benton, C. F. (2012). The Great Divide: Examining Football Revenue among FBS Schools // International Journal of Sports Science \& Coaching. Vol. 7, No. 2, p. 345-369.

7. Czekanski, W. A., Barnhill, C. R. (2015). Recruiting the Student-athlete: An Examination of the College Decision Process // Journal for the Study of Sports and Athletes in Education. Vol. 9, No. 3, p. 133-144.

8. Dumond, J. M., Lynch, A. K., Platania, J. (2008). An Economic Model of the College Football Recruiting Process // Journal of Sports Economics. Vol. 9, No. 1, p. 67-87.

9. Langelett, G. (2003). The Relationship between Recruiting and Team Performance in Division 1A College Football // Journal of Sports Economics. Vol. 4, No. 3, p. 240-245.

10. Liker, J. K., Fleischer, M., Arnsdore, D. (1992). Fulfilling the Promises of CAD // Sloan Management Review. Vol. 33, No. 3, p. 74.

11. Magnusen, M., Kim, Y., Perrewé, L., Ferris, G. (2014). A Review and Synthesis of Student-athlete College Choice Factors: Recruiting Effectiveness in NCAA Sports // International Journal of Sports Science \& Coaching. Vol. 9, No. 6, p. $1265-1286$.

12. Maxcy, J. G. (2013). Efficiency and Managerial Performance in FBS College Football: To the Employment and Succession Decisions, Which
Matters the Most, Coaching or Recruiting? // Journal of Sports Economics. Vol. 14, No. 4, p. 368-388.

13. Maxcy, J. G. (2008). The Economics of Sport and the Media // International Journal of Sport Communication. Vol. 1, No. 1, p. 127-131.

14. Rivals.com (2017). 2017 Illinois Commitment List. Internet access: $<$ https://illinois.rivals.com/ commitments/football/2017> [accessed March 10, 2017].

15. Rivals.com (2017). 2017 Iowa Commitment List. Internet access: <https://iowa.rivals.com/ commitments/football/2017> [accessed March 10, 2017].

16. Rivals.com (2017). 2017 Minnesota Commitment List. Internet access: <https://minnesota. rivals.com/commitments/football/2017> [accessed March 10, 2017].

17. Rivals.com (2017). 2017 Nebraska Commitment List. Internet access: <https://nebraska. rivals.com/commitments/football/2017> [accessed March 10, 2017].

18. Rivals.com (2017). 2017 Northwestern Commitment List. Internet access: <https://northwestern.rivals.com/commitments/football/2017> [accessed March 10, 2017].

19. Rivals.com (2017). 2017 Purdue Commitment List. Internet access: <https://purdue.rivals.com/ commitments/football/2017> [accessed March 10, 2017].

20. Rivals.com (2017). 2017 Wisconsin Commitment List. Internet access: <https://wisconsin. rivals.com/commitments/football/2017> [accessed March 10, 2017].

21. Rosenberger, A. L. (2014). Northwestern University and College Athletes Players Association // Journal of Collective Bargaining in the Academy. Vol. 6, No. 1, p. 74.

22. Treadway, D. C., Adams, G., Hanes, T. J., Perrewé, P. L., Magnusen, M. J., Ferris, G. R. (2014). The Roles of Recruiter Political Skill and Performance Resource Leveraging in NCAA Football Recruitment Effectiveness // Journal of Management. Vol. 40, No. 6, p. 1607-1626.

The paper submitted: March 10, 2017 Prepared for publication: May 30, 2017 
Kevin A. DIEHL

\title{
KAIP LAIMĖJO VAKARỤ DIDYSIS DEŠIMTUKAS: FUTBOLININKU PRITRAUKIMAS I KOMANDA
}

\author{
S a n t r a u k a
}

Šiandien, norint būti sèkminga organizacija tarptautinëje rinkoje, neužtenka siūlyti kokybiškų produktų ir paslaugų, privaloma nusamdyti kompetentingus darbuotojus. Sporto pasaulyje komandos komplektavimas yra svarbiausias prioritetas. Vakarų didžiojo dešimtuko futbolo diviziono žaidejų viliojimo laikotarpis pasirinktas kaip studijų laukas komplektavimo objektui tirti. Naudojama metodologija remiasi Rivals.com suteikiamais taškais kiekvienam atletui. Pagal kriterijus renkami taškai nuo 5,1 iki 6,1. 100 yra tarpinis etapas. 100 taškų skiriama už žaidejo priviliojimą iš tolimesnių nei aplinkinių valstijų, 75 taškai - kaimyninių valstiju ir 0 taškų už vietinès valstijos (universiteto valstija). Tai svarbu vertinant politinius sugebejjimus privilioti žaidejąa i komandą. Vietinius žaidèjus žymiai lengviau pritraukti, nes jie „užaugę" su universiteto komanda. Papildomi taškai skiriami už atletus iš kitų valstijų, kurie savanoriškai dalyvauja komandos atrankoje (100 ir 75 taškai). Tyrimas atskleidžia, kurių universitetų komandos treneriai, pasitelkę politinius sugebèjimus, sèkmingiausiai privilioja žaidejjus ¡̇ universiteto futbolo komandą. Kadangi papildomi viliojimo įrankiai tokie kaip didesnès stipendijų sumos yra apriboti, sèkmingo žaidèjo viliojimas priklauso nuo trenerio politinių gebẻjimų. Žaidejjai iš kitų valstijų nèra tokie lojalūs kaip vietiniai, tad už jų priviliojimą skiriama daug daugiau taškų. Iš esmès politiniai gebejjimai praverčia, kai žaidèjui bandoma įrodyti, kad siūlomo universiteto programa gali jam padèti pasiekti aukštų sportinių rezultatų, profesionalios karjeros. Treneris, noredamas pritraukti atletą, turi atskleisti programos stipriąsias ir paslèpti silpnąsias vietas. Dažniausiai universiteto atstovai mini: žaidimo laiką, buvusių studentų sèkmès istorijas NFL, sporto salių kokybę, aistruolių skaičių, viešosios komunikacijos pasiekiamus rezultatus ir galimybes laimèti nacionalinị čempionatą. Galutinè rezultatų rikiuotè: Iowa, Nebraska, Wisconsin, Northwestern, Illinois, Minnesota ir Purdue universitetas. Tai reiškia, kad Iowa universiteto futbolo komandos treneris turi puikių politinių gebejimų ir sèkmingai pateikęs universiteto sporto programos privalumus tarp Vakarų didžiojo dešimtuko futbolo diviziono atstovų pritrauke daugiausia reikiamų žaidèjų. Ateityje mokslininkams šis tyrimas padès nustatyti esminius veiksnius, lemsiančius atletų pritraukimą. Tai gali būti kaip edukacinè priemonè vadybininkams, kurie nesusiję su sportu. Kitaip nei universitetu treneriai, kurie gali pasiūlyti ribotą atlygị (stipendiją), vadybininkai gali tikètis didesnio atlygio. Tyrimas atskleidžia, kaip maksimizuoti galimus privalumus ir taip pasiekti savo tikslą pritraukti darbuotoją ir žaidejją. 